\title{
Zonas áridas
}

\author{
Convencidos de la necesidad de incorporar criterios \\ de economía, y controlar la tendencia al consumo y \\ a la explotación de recursos que parece regir nuestra \\ cultura, esta vez reflexionamos en torno a la relación \\ entre arquitectura y medio ambiente en las zonas más \\ secas y calurosas de América. Ambito de asentamientos \\ precolombinos y oficinas salitreras, la realidad implacable \\ de los desiertos en Lima, Atacama y Arizona está \\ fuertemente determinada por condiciones ambientales \\ adversas; sin embargo ba originado una arquitectura de \\ sombras, espacios abiertos y jardines que bacen de la \\ escasez del agua y la abundancia de sol, una virtud. \\ Palabras clave: Zonas áridas, asentamientos precolombinos, desierto de \\ Atacama, Lima, desertificación, desierto de Sonora, ciudad jardín.
}

Convinced of the need to incorporate economic criteria and curb the prevailing trend in our culture towards consumption and over-exploitation of resources, we are drawn to reflect on the relationship between architecture and environment in the hottest, driest areas of America. The implacable deserts of Peri. Chile and Arizona, settings in the past for preColombian settlements and nitrate mines, are the stage for the projects we present in this edition. Defined by bostile environment they bave nevertheless created an architecture of shadow, open spaces and gardens that make a virtue of scarce water and abundant sun. 


\section{La ciudad jardín en los suburbios del desierto de Sonora Ignacio San Martín}

\section{La persistencia del sueño suburbano}

El objetivo de este ensayo es presentar un análisis que explique las consecuencias de implementar el sueño norteamericano suburbano en la región sudoeste, tomando como caso de estudio el área metropolitana de Phoenix, una de las regiones de más reciente y rápida expansión en los Estados Unidos. Antes y para mayor claridad, es necesaria una breve introducción que explique el contexto cultural responsable de la preferencia estadounidense por la vida en los suburbios: el subproducto de un profundo deseo cultural y psicológico por el espacio abierto, la movilidad sin restricciones $y$, hasta cierto punto, la desconfianza hacia el modo de vida y las políticas de las grandes ciudades.

\section{Garden city suburbs in the Sonoran Desert Isnacio San Martín}

The persistence of the suburban dream The objective of this essay is to present an analysis explaining the consequences of implementing the American suburban dream in the Southwest region using the Phoenix Metropolitan Area (one of the newest and most rapidly expanding regions of the United States) as a case study. As a matter of clarity, however, it is necessary to provide a brief introduction explaining the cultural setting responsible for the American preference for suburban living: A byproduct of a deep cultural and psychological desire for open space, unrestrained mobility, and to some degree, a mistrust for big city lifestyles and politics.

\begin{abstract}
"El desarrollo norteamericano se explica por la existencia de un área de tierra libre, su continua reducción y el avance del asentamiento estadounidense bacia el oeste. Como se ba indicado, la frontera produce individualismo. Los nuevos territorios babitados precipitan que una sociedad compleja se organice de un modo primitivo centrado en la familia. Es una tendencia antisocial, que se opone al controly especialmente, a cualquier control directo". Frederick Jackson Turner, 1893
\end{abstract}

Esta cita de fines del siglo XIX de Frederick J. Turner se presenta aquí como un signo de las peculiaridades de la experiencia estadounidense con respecto a nuestra tendencia regional de asentamientos humanos. Es por eso que para entender las actuales condiciones de extensión suburbana en las ciudades norteamericanas es necesario adentrarse en las fuentes culturales e ideológicas que llevaron a que Estados Unidos aceptase la vida en los suburbios como símbolo de un modo distintivamente norteamericano de construcción de la democracia.

El origen de este ideal democrático ya está presente en la preocupación que manifiesta Jefferson por mantener el nuevo país como una civilización agraria, sentimiento que siguió siendo

\section{"The existence of and area of free land, its continuous recession, and the advance of American settlement westward, explain American development. As bas been indicated, the frontier is productive of individualism. Complex society is precipitated by the wilderness into a kind of primitive organization based on the family. The tendency is anti-social. It produces antipatby to control, and particularly to any direct control". Frederick Jackson Turner, 1893}

This quote from Frederick J. Turner at the close of the 19th century is presented here as a signal of the peculiarities of the American experience with respect to our regional expression of human settlements. Therefore, to understand the current conditions of suburban sprawl in American cities requires an inquiry into the cultural and ideological sources that guided the United States to accept suburban living as a symbol of a distinctive American construct of democracy.

The origin of this democratic ideal is already present in Jefferson's preoccupation with maintaining the new country as an agrarian civilization, a sentiment that continued to be the source of unceasing preoccupation in the fuente de inquietud incesante en la literatura de fines del siglo XIX (Jefferson, 1785). Por ejemplo, en su artículo Progreso y pobreza (1879), Henry George condenó a la ciudad como la principal fuente de producción de "la más profunda pobreza, la más aguda lucha por la existencia y la más forzosa inactividad". Para George, las ciudades eran el foco de poder productivo capitalista y el subproducto de escasez y miseria para un gran número de sus ciudadanos. Por ello, la descentralización de los individuos desde las ciudades congestionadas era necesaria como un modo de liberar al ciudadano estadounidense hacia un nuevo modelo de civilización. Era condición que la propiedad de la tierra fuese "el becho fundamental que finalmente determina la condición social, política y, por ello, intelectual y moral de una persona". Paradojalmente, no era el sentimiento agrario en sí lo que permitía alcanzar una democracia descentralizada, sino los resultados de la industrialización y las innovaciones en tecnología de transportes que dinamizaban el impulso económico (fig. 1).

Como tal, el suburbio jardín residencial aparece en Estados Unidos más de medio siglo antes del ensayo de Henry George, si consideramos las subdivisiones residenciales de Tompkinsville (1814) y los ferry-suburbs ${ }^{1}$ de New Brighton (1836), literature of the late 19th century. (Jefferson, 1785). For instance, Henry George in his article Progress and Poverty (1879) critically condemned the city as the principal source of producing "the deepest poverty, the sharpest struggle for existence and the most enforced idleness". For George, the cities were the focus of capitalist productive power and the byproduct of squalor and misery for a large number of its citizens. Thus, the decentralization of individuals from the congested cities was a necessity as a means of freeing the American citizen into a new pattern of civilization. It was a condition whereby the ownership of land would be "the fundamental fact which ultimately determines the social, political, and, consequently, the intellectual and moral condition of a people". Paradoxically, it was not the agrarian sentiment, in itself, that allowed the achievement of a decentralized democracy, but the fruits of industrialization and new innovations in transportation technologies that energized the economic drive for decentralization (fig. 1).

As such, the residential garden suburb appears in U.S.A. prior Henry George's essay by over half a century if we account for the residential subdivisions of Tompkinsville (1814) and New 
en Staten Island. Al poco tiempo les siguieron Llewelling Park (1853), Lake Forest (1856) y Riverside (1869) entre otras, concluyendo con el trabajo de síntesis de Clarence Stein en Radburn (1928). Pero es quizás la propuesta Usonian de Frank Lloyd Wright para la ciudad de Broadacre (1935) la que mejor sintetiza la ideología (y las problemáticas consecuencias) de la descentralización suburbana en los Estados Unidos después de la década de los cincuenta. En Broadacre, la principal preocupación de Wright es crear un consenso suburbano por el que la ciudad pueda encontrarse "en todas y en ninguna parte". La tendencia antiurbana de Broadacre es la de un agrario de corazón, enamorado de las nuevas tecnologías y deseoso de una forma dispersa de civilización en la que, como lo sintetiza Kenneth Frampton, el automóvil sea el único agente democrático. Por eso, el fenómeno suburbano que caracterizó gran parte del crecimiento posterior a los años cincuenta a lo largo de las Sunbelt regions ${ }^{2} \mathrm{de}$ los Estados Unidos tiene raíces intelectuales profundas y numerosos profetas (fig. 2).

El desierto de Sonora no es Wisconsin, Nueva Inglaterra ni Virginia

El pedazo sudoeste del estado de Arizona contiene un paisaje de dura topografía y diversidad ecológica. Algo así como la mitad de este territorio -conocido como el sector de la meseta de Arizona dentro del desierto de Sonora- es una región destacada por su inusual bosque de saguaros y palos verde, y el único área al interior del desierto de Sonora que muestra un calor extremo en el verano además de frecuentes y severos hielos durante el invierno. Los actuales niveles de precipitación en el desierto de Sonora dentro de Arizona van desde una cifra tan baja como $75 \mathrm{~mm}$ anuales en su margen oeste, a los 120 a $250 \mathrm{~mm}$ en las cercanías de Phoenix, y a los 200 a $304 \mathrm{~mm}$ anuales en la cuenca de Tucson (Dimmitt, 2000). En consecuencia, el principal indicador y el factor más evidente al cual debe adaptarse el régimen ecológico es la aridez. Y la adaptación es la lección que más prevalece en este paisaje.

Aquí los organismos se adaptan ya sea acumulando agua (si son tolerantes a ella) o evitando la sequía, al permanecer inactivos la mayor parte del año. La estrategia en este ecosistema es evitar el contacto directo con el sol, ya sea viviendo bajo tierra o teniendo períodos de actividad durante la noche. Este requerimiento de sombra ha dotado a muchos mamíferos de la habilidad de crear sus propios microclimas, y la mayoría de los pequeños mamíferos escogen adaptarse cavando hoyos en el suelo como estrategia de hábitat. El resultado de esta adaptación es que, para mantener un nivel saludable de biodiversidad regional, debe preservarse el hábitat y alterar lo menos posible el primer metro y medio de capa de suelo desértico.

\section{Características del desarrollo suburbano} post década de los cincuenta

Es importante destacar que la década de los cincuenta representa un período de importantes cambios en la producción industrial y económica de la nación. Básicamente, la principal capacidad productiva en el país pasó de una base industrial a una nueva industria de servicios, investigación y desarrollo. Pero lo que impulsó la gran descentralización suburbana fue una inyección de fondos federales para construir nuevas autopistas -en conjunto con grandes subsidios para estimular la construcción y compra de viviendas- y la creación de subsidios energéticos para reducir el precio de la gasolina. Como tal, la magnitud del desarrollo después de los años cincuenta refleja una diferencia drástica con respecto a la extensión promedio del desarrollo suburbano de la década de los veinte. Las nuevas subdivisiones residenciales de los años sesenta -tales como Columbia,
Brighton (1836) ferry-suburbs ${ }^{1}$ in Staten Island. They were soon followed by Llewelling Park (1853), Lake Forest (1856) and Riverside (1869) among others, ending with the work of Clarence Stein's synthesis at Radburn (1928).

But it is perhaps the work of Frank Lloyd Wright's Usonian proposition for Broadacre City (1935), that best encapsulates the ideology (and problematic consequences) of suburban decentralization in the U.S.A. after 1950's. In Broadacre, Wright's principal preoccupation is that of creating a suburban compromise where the city is to be found "everywhere and nowbere". Broadacre's anti-urban expression is that of an agrarianist at heart in love with the new technology, and a desire for a dispersed form of civilization where, as Kenneth Frampton succinctly put it, the car is the only democratic agent. Therefore, the suburban expression that characterized much of the post 1950s growth along the Sunbelt regions ${ }^{2}$ of the United States has deep intellectual roots and numerous prophets (fig. 2).

The Sonoran Desert is not Wisconsin, New England, or Virginia

The southwestern portion of the State of Arizona comprises a landscape of severe topography as well as ecological diversity. About half of this terrain, known as the Arizona Upland section of the Sonoran Desert, is a region notorious for its unusual saguaro-palo verde forest, and the only subdivision within the Sonoran Desert exhibiting extreme summer heat and frequent hard winter frosts (fig. 3). Current precipitation in Arizona's portion of the Sonoran Desert range from as low as 3 inches per year in its western margin, to 5 to 10 inches in the vicinity of Phoenix, and 8 to 12 inches per year in the Tucson basin (Dimmitt, 2000). Consequently, aridity is the major indicator and the most evident factor to which the ecological regime must adapt. And adaptation is the most prevalent lesson in this landscape. The organisms here adapt either by storing water, being water tolerant, or avoiding the drought by being dormant most of the year. Thus, the strategy in this ecosystem is avoidance of direct contact with sun, either by living underground or by being active after sunset. This requirement for shade has equipped many mammals with the ability to create their own microclimates, with burrowing adaptation being a selected habitat strategy for most small mammals. The outcome of this adaptation is that to maintain a healthy level of regional biodiversity, it requires habitat preservations and a minimal disturbance of at least the first five feet of desert soil.

Post 1950s suburban development characteristics

It is important to point out that the 1950 s represent a period of important shifts in the industrial and economic production in the nation. Basically, the principal economic output in the country changed from a former industrial base production to a new service and $R \& D$ industries. But the large suburban decentralization was encouraged by an infusion of Federal funds to build new freeways, in conjunction with large subsidies to stimulate the production and purchase of single-family residential dwellings, and the creation of energy subsidies to reduce the price of gasoline. As such, the magnitude of development after the 1950s reflects a drastic difference with respect to the average size of suburban development of the 1920s. The new residential subdivisions of the 1960s such as Columbia, Maryland; Reston Virginia; Irvine California among others are now considerably larger $(5,10$ or 40 thousand acres at a 


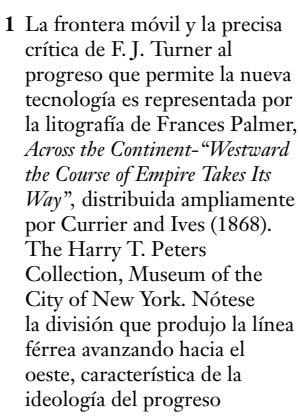

Maryland, Reston Virginia e Irvine California, entre otras- son ahora considerablemente más grandes (2, 4 ó 16 mil hectáreas a la vez) y con un ritmo de desarrollo mucho más rápido que el de cualquier período previo de desarrollo residencial en la historia del país.

Estas nuevas ciudades-como se las llamó- aplican el Plan Unit Development (PUD) de residencias principalmente particulares, separadas de centros comerciales, extensos espacios abiertos para campos de golf, y un sistema de transporte basado en el automóvil particular. Esencialmente, el PUD favorece una menor densidad poblacional -con una distribución promedio de unas 1.900 personas por $\mathrm{km}^{2}-$, en contraste con, por ejemplo, San Francisco, que tiene una densidad poblacional de alrededor de 7.000 personas por $\mathrm{km}^{2}$. En comparación, el área metropolitana de Phoenix, el foco de este debate, comprende hoy un área suburbanizada de alrededor de $7.700 \mathrm{~km}^{2}$, con una población metropolitana de unas 3.000 .000 de personas, a una densidad promedio de asentamiento (en tierras urbanizadas) de 900 personas por $\mathrm{km}^{2}$ (fig. 3).

El área metropolitana de Phoenix

Desde sus orígenes en 1871, la cuenca de Phoenix

time) and with a rate of development that is much faster than at any preceding period of residential development in the history of the country.

These new cities as they were called, replicate a Plan Unit Development (PUD) of primarily single-family residences, separate clusters of commercial centers, large open spaces dedicated for golf course recreation, and a transportation system based on the private automobile. In essence, the PUD favors lower population densities of an average distribution of about 5.000 persons per square mile, in contrast to, for instance, San Francisco that has a population density of about 18,000 persons per square mile. As a comparison, the Phoenix metropolitan area, which is the focus of this discussion, comprises today a suburbanized area of about 3,000 square miles, with a metropolitan population of about 3 million persons at an average settlement density (on developed land) of about 2.300 persons per square mile. (fig. 3)

\section{The Phoenix Metropolitan area}

Since its origin in 1871, the Phoenix basin has experienced a series of migrations resulting in sporadic growth rates in the region. By 1918,
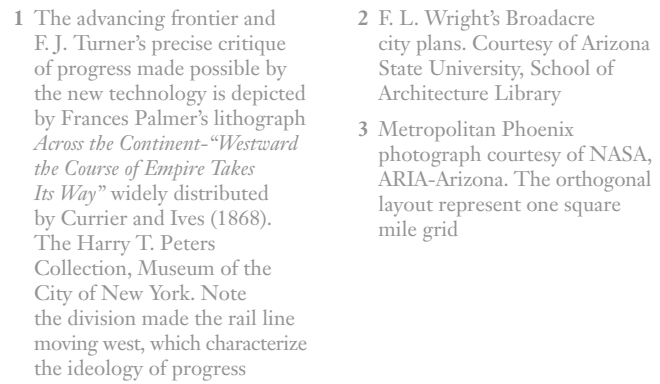

ha experimentado una serie de migraciones que inciden en crecimientos demográficos esporádicos en la región. Hacia 1918, el cultivo principal era el algodón, aunque fue el excelente clima de la zona lo que contribuyó a su popularidad como un importante resort de salud (Luckingham, 1984). Para 1929, el turismo encendió las primeras ideas de expansión suburbana con el desarrollo de la industria hotelera. Por ello, en 1971 el área metropolitana de Phoenix contaba con 971.000 habitantes, los que aumentaron a 2.783 .000 personas en 1998 (Morrison Institute for Public Policy, 2000). Existen diversos enfoques que explican este impresionante crecimiento, y diferentes estrategias de investigación que miden las implicancias ecológicas, sociales y humanas de esta expansión. Por ejemplo, si tomamos como vara de medida los últimos treinta años, el incremento de la población ha sido de 1.400 .000 habitantes, de las cuales se estima que un $64 \%$ (900.000) se concentra en los últimos quince años. Este crecimiento reciente indica un aumento poblacional promedio de 60.000 nuevos residentes por año, lo cual se corresponde con las estadísticas de construcción, que reflejan el aumento anual de unas 32.000 residencias particulares. Quizás aún más dramático es que

cotton farming was the dominant crop, but it was the excellent climate that contributed to its regional popularity as an important health resort (Luckingham, 1984). By 1929, tourism provided the first desire for suburban expansion with the development of the resort hotel industry. Subsequently, by 1970, metropolitan Phoenix had a population of 971,000 , increasing once more to about 2,783.000 by 1998 (Morrison Institute for Public Policy, 2000) (fig. 6). There are various approaches to portray this astonishing growth and different research strategies to measure the ecological, social, and human implications of this expansion. For instance, taking the last 30 years as a measuring rod, the increase in population is 1.400.000 persons, out of which, an estimated $64 \%(900.000)$ has taken place within the last 15 years. This newest growth indicates an average population increase of 60.000 new residents per year, which correlates with the construction statistics reflecting a growth of about 32.000 new single-family residences per year. More dramatic perhaps is that the settlement density (persons per square mile) as a whole has not changed much over the past 30-years from that of 2.200 in the 1970 s to 2.700 in the 1990 s (San Martín,
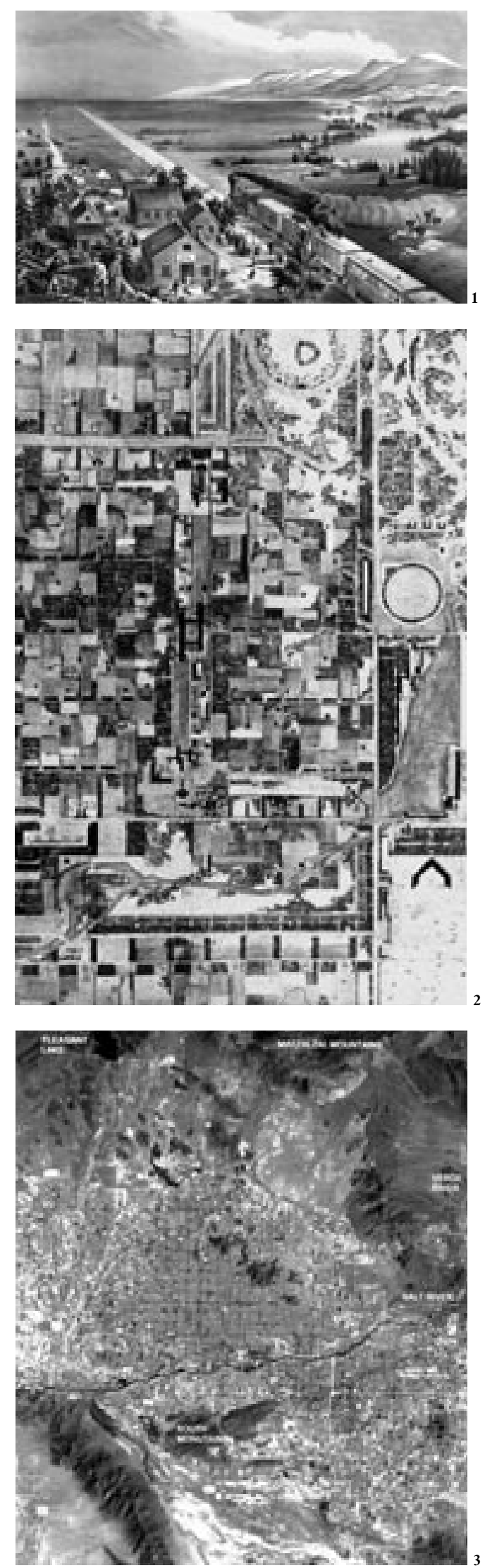


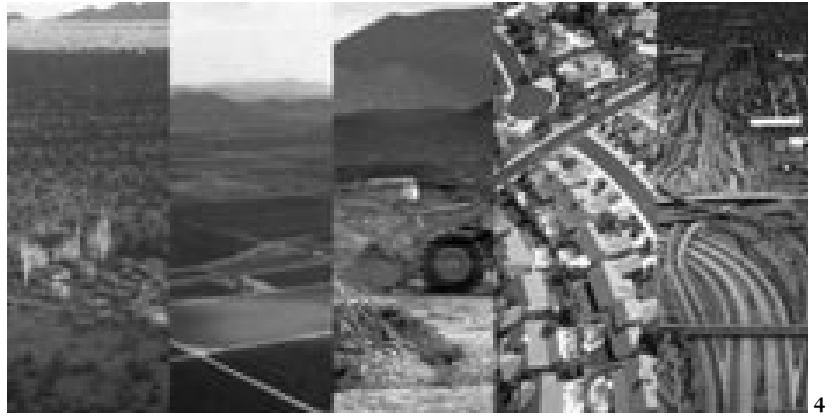

ARQ la densidad de asentamiento (personas por $\mathrm{km}^{2}$ ) no ha cambiado mucho en los últimos treinta años: desde 850 en los años setenta a 1.040 en los años noventa (San Martín, 1996). En cuanto a la disponibilidad de terrenos, este sorprendente crecimiento poblacional -distribuido de acuerdo a las densidades suburbanas recién descritassignifica un impacto profundo en el paisaje regional. Con esta densidad suburbana, el ritmo de cambio en el paisaje alcanza algo así como 0,6 hectáreas por hora. Esto lleva a una reducción oficial de un $40 \%$ en los recursos de suelo agrícola y un $32 \%$ de tierra desértica tan sólo en los últimos veinte años (Arizona State University, proyecto CAP-LTER fase I, y Morrison Institute for Public Policy, 2000). Lo inquietante no son sólo estos enormes porcentajes. Se estima que un $52 \%$ del paisaje terminará pavimentado para hacer caminos, autopistas o parques de estacionamientos (fig. 4).

El 95\% del transporte en el Phoenix metropolitano es a través de vehículos particulares, y no parece que esta cifra vaya a cambiar en el futuro. Aquí el impacto es más directo en el ámbito de la contaminación del aire y su repercusión en la salud humana. Aunque se hacen esfuerzos para mejorar la calidad del aire en la región, el informe de 1994 de la Asociación Estadounidense del Pulmón indicaba que la contaminación del aire le costaba al Phoenix metropolitano US\$ 431.000 .000 al año, con un $64 \%$ atribuido al deterioro de la salud de sus habitantes. Las tres principales fuentes de contaminación del aire son PM10 (partículas en suspensión menores a los 10 micrones), ozono, y monóxido de carbono. La contaminación por PM10 es una gran fuente de cuidado, y un $69 \%$ proviene del transporte particular. Las condiciones climáticas no ayudan a aliviar el problema: días cálidos, poca lluvia y falta de una vegetación frondosa.

El desarrollo residencial de baja densidad generalmente produce un exceso de viajes y congestión, a la vez que reduce el tiempo de viaje al trabajo. De acuerdo al Departamento de Transportes de Arizona, casi el 50\% de los viajes en la zona metropolitana de Phoenix toma entre 10 y 25 minutos, pero el tiempo promedio de viaje al trabajo, sin embargo, es de 22 minutos. El resultado final es que los sectores suburbanos de baja densidad pueden reducir el tiempo de desplazamiento, pero la expansión en el uso del suelo y la falta de un ambiente peatonal son responsables de que se generen más viajes

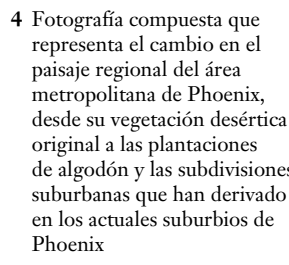

4 Fotografía compuesta que representa el cambio en el paisaje regional del área metropolitana de Phoenix, desde su vegetación desértic original a las plantaciones de algodón y las subdivisiones suburbanas que han derivado en los actuales suburbios de Phoenix

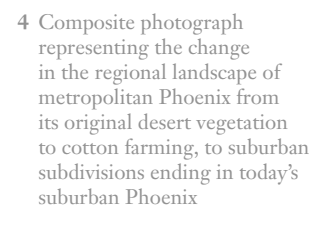

cortos. Más viajes requieren de más caminos y, para aliviar la congestión, la construcción de más kilómetros de autopistas. Aunque el desarrollo vial es apoyado por el gobierno federal, los fondos que se necesitan en el área metropolitana de Phoenix para financiar la mayor construcción de autopistas requieren que se asigne el $62 \%$ del impuesto al consumo más un $20 \%$ adicional de las tarifas tradicionales de uso, también conocidas como "impuesto a la gasolina" (Departamento de Transportes de Arizona, 1995). Esto significa que un gran monto del ingreso líquido generado por las ciudades a través del impuesto al consumo se destina a extender las autopistas y no a mejorar los servicios comunitarios y sociales.

\section{Lecciones de la experiencia de Phoenix}

Quizás el impacto negativo más obvio que hoy afecta al área metropolitana de Phoenix sea la calidad del aire y su efecto en la salud de los habitantes. Pero la preponderancia del automóvil particular como el principal medio de transporte tiene múltiples repercusiones. Además de su dañino efecto en la calidad del aire, requiere de una vasta inversión en la construcción de autopistas y otras arterias de transporte. Sin embargo, construir más
1996). In terms of land resources, this staggering population growth distributed at the above suburban densities, equates to serious impacts on the regional landscape. At these suburban densities, the rate of landscape change reaches (by now a popular number) of about 1.5 acres per hour. This has resulted in a recorded reduction of $40 \%$ of the agricultural land resources and $32 \%$ of the desert land within the past 20 years alone (Arizona State University, proyecto CAPLTER phase I, and Morrison Institute for Public Policy, 2000). The distressing news is by no means the only large percentages quoted. It is estimated that $52 \%$ of the landscape change ends up being paved either by roads, highways, or parking lots (fig. 4).

The form of transportation in metropolitan Phoenix is $95 \%$ by private vehicle and this figure does not look any different in the future. The impact here is more directly in the area of air pollution and its repercussions to human health. While efforts are being made to improve the air quality of the region, the 1994 report by the American Lung Association indicated that the cost to metropolitan Phoenix due to air pollution amounted to US\$ 431 million per year, with
$64 \%$ attributed to human health. The three main source of air pollution are PM10 (particles smaller than 10 microns), ozone, and carbon monoxide. PM10 pollution is a major source of concern with $69 \%$ of particulate associated to private transportation (fig. 8). The climatic conditions of hot weather, little rain, and lack of dense vegetation do not help to alleviate the problem. Low-density residential development generally creates excess travel and congestion while reducing the commuting time to work. According to the Arizona Department of Transportation, almost $50 \%$ of the trips in metropolitan Phoenix range from 10 to 25 minutes but the mean commuting time, however, is 22 minutes. The end result is that low-density suburban developments can reduce commuting times, but the spread of land uses and the lack of a pedestrian environment are responsible for increasing the number of shorter trips generated. More trip generation requires more roads and, to remedy congestion, the construction of more freeway miles. While freeway development is supported by the Federal Government, in metropolitan Phoenix the needed matching funds to compensate for highway construction requires the allocation of $62 \%$ of the sales tax plus an additional $20 \%$ from traditional user fees, otherwise know as gasoline tax (Arizona Department of Transportation 1995). This means that a large amount of disposable income generated by cities from sales tax is dedicated to the cost of highway expansion rather than improving community and social services (Fig. 9).

Lessons From the Phoenix Experience Perhaps the most obvious adverse impact taking place the metropolitan Phoenix is that of air quality and its association with the health of its residents. But the predominance of the private automobile as the primary form of transportation has multiple repercussions. In addition to its detrimental effect on air quality, it requires vast investments in the construction of highways and other transportation arteries. Yet, building more freeways does not guarantee less traffic congestion. The paradigm shift in transportation engineering is not how to move cars but how to move people, and the experience in the USA indicates that building more freeways generates more prospects for suburban sprawl. The consequences of this are multiple, not the 
autopistas no garantiza una menor congestión de tráfico. El giro paradigmático en la ingeniería de transporte no radica en cómo movilizar los autos sino cómo movilizar personas, y la experiencia estadounidense indica que construir más autopistas genera mayores posibilidades de extensión suburbana. Las consecuencias de algo así son múltiples, entre las cuales no es menor un aumento del efecto de isla térmica asociado a la radiación del calor desde el asfalto y las superficies de concreto (algo que se exacerba durante los meses de verano), y un notable aumento en el total de superficie impermeable. Lo primero es, entre otros factores, responsable del aumento de las temperaturas nocturnas, y lo último requiere de la construcción de grandes sistemas de drenaje que minimicen el potencial riesgo de inundación por las lluvias monzones de verano.

Quizá sea más difícil describir las consecuencias sociales que presenta el desarrollo extendido. Algunos autores (Hayward y Condole, 1996) han argumentado que la extensión suburbana es el subproducto de dos fuerzas: una economía local fuerte y las preferencias de los compradores residenciales. De hecho, en las últimas dos décadas el crecimiento económico del área metropolitana de Phoenix se ha visto reflejado en una significativa expansión de los servicios gubernamentales, las industrias turística, espacial y computacional, y el establecimiento de diversas sucursales de importantes corporaciones de seguros de vida, bienes raíces y finanzas. Sin embargo, pese a este dinamismo en el ámbito económico existen claras indicaciones de que el extenso y veloz crecimiento suburbano produce graves inequidades sociales (Guhathakurta y Wichert, 1996). Esto se hace más evidente cuando áreas suburbanas específicas absorben la mayor parte del desarrollo residencial y forman comunidades dormitorio, mientras el uso comercial de los terrenos se desplaza hacia comunidades más prósperas y políticamente poderosas (San Martín, 1998). Como tal, el paisaje social del área metropolitana de Phoenix es el de comunidades segregadas por raza y clase social, sin interacción pública y un declive general en civilidad y convivencia urbana. Pero quizás una de las lecciones más importantes aprendidas en Estados Unidos, así como en el área metropolitana de Phoenix, sea que una vez que las fuerzas políticas y económicas de la extensión suburbana surgen en una región, administrarlas requiere de un compromiso social y una voluntad política dignos de Hércules. aRq
Bibliografía: Arizona State University, CAP-LTER project phase I, y Morrison Institute for Public Policy, septiembre de 2000. / Dimmitt, Mark A.; Biomes \& Communities of the Sonoran Desert Region, en Phillips, Phillips, Steven J. y Wentworth Comus, Patricia; $A$ Natural History of the Sonoran Desert. Arizona-Sonora Desert Museum y University of California Press, Tucson, 2000. / Guhathakurta, Subhrajit y Wichert, Michele; Who Pays for Growth in the City of Phoenix? An Equity Based Perspective on Suburbanization. School of Planning and Landscape Architecture, Arizona State University, Phoenix, 1996. / Hayward, Steven y Condole, Erick; "Growth in the Phoenix Metropolitan Area: A Primer on Policy Choices". Arizona Issue Analysis Reporte \#137, Goldwater Institute, Phoenix, 1996. / Jackson Turner, Frederick; The Significance of the Frontier in American History, 1893, en Weimer, David; City and Country in America. Appleton - Century - Crofts, Nueva York, 1962, pp. 69-74. / Jefferson, Thomas; Notes on the State of Virginia, 1785, en Weimer, David; City and Country in America. Appleton - Century - Crofts, Nueva York, 1962, pp. 28-30. / Luckingham, Bradford; "The American Southwest: An Urban View". Western Historical Quarterly, Logan, julio de 1984, pp. 261-280. / Morrison Institute for Public Policy, Tempe, Arizona, septiembre de 2000. / San Martín, Ignacio; "Questioning the American Dream: Regional Planning v the Metropolitan Phoenix". CIUDADES 3, Instituto de Urbanística, Ediciones Universidad de Valladolid, Valladolid, 1996, pp. 67-95. / San Martín, Ignacio; Tow of Gilbert: The Cost of Community Services. Herberger Center for Design Excellence, College of Architecture, Arizona State University, Tempe, 1998. least of which are an increase in the heat island effect associated with the radiation of heat from asphalt and concrete surfaces (a condition that exacerbates during the summer months), and a notable increase in overall amount of the impervious surface. The former is responsible for increasing (among other factors) night time temperatures while the latter requires the construction of massive drainage systems to minimized the risk of flooding potential from the violent summer monsoon rains.

The social consequences of sprawl development are perhaps more elusive to describe. Some authors (Hayward and Condole, 1996) have argued that suburban sprawl is the byproduct of two forces: a strong local economy and homebuyer's preferences. Indeed, in the last two decades, metropolitan Phoenix have expanded its local economy with a significant expansion in government services, resort and tourism industry, aerospace and computers industries, and a diversity of branch offices from important national insurance, real estate, and finance corporations. Yet, despite this activity in the economic arena, there are clear indications that large and rapid suburban growth produces serious social inequities (Guhathakurta and Wichert, 1996). This is more evident when specific suburban areas absorb most of the residential development forming bedroom communities, while retail and valuable commercial land uses move to the most prosperous and politically powerful communities (San Martín, 1998). As such, the social landscape of metropolitan Phoenix is that of communities segregated by ethnic and social class lacking in public interaction, with an overall decline in civility and urban livability. But perhaps one of the most important lessons learned in the USA, as well as in metropolitan Phoenix, is that once the political and economical nature of suburban sprawl has taken place in a region, its management requires a Herculean social commitment and political will. ARQ
Bibliography: Arizona State University, CAP-LTER project phase I, and Morrison Institute for Public Policy, September 2000./Dimmitt, Mark A.; Biomes \& Communities of the Sonoran Desert Region, in Phillips, Phillips, Steven J. y Wentworth Comus, Patricia; A Natural History of the Sonoran Desert. Arizona-Sonora Desert Museum and University of California Press, Tucson, 2000. / Guhathakurta, Subhrajit and Wichert, Michele; Who Pays for Growth in the City of Phoenix? An Equity Based Perspective on Suburbanization. School of Planning and Landscape Architecture, Arizona State University, Phoenix, 1996. / Hayward, Steven and Condole, Erick; "Growth in the Phoenix Metropolitan Area: A Primer on Policy Choices". Arizona Issue Analysis Report \#137, Goldwater Institute, Phoenix, 1996. / Jackson Turner, Frederick; The Significance of the Frontier in American History, 1893, in Weimer, David; City and Country in America. Appleton - Century - Crofts, New York, 1962, pp. 69-74. / Jefferson, Thomas; Notes on the State of Virginia, 1785, in Weimer, David; City and Country in America. Appleton - Century - Crofts, New York, 1962, pp. 28-30. Luckingham, Bradford; "The American Southwest: An Urban View". Western Historical Quarterly, Logan, July 1984, pp. 261-280. / Morrison Institute for Public Policy, Tempe, Arizona, September 2000. / San Martín, Ignacio; "Questioning the American Dream: Regional Planning the Metropolitan Phoenix". CIUDADES 3, Instituto de Urbanística, Ediciones Universidad de Valladolid, Valladolid, 1996, pp. 67-95. / San Martín, Ignacio; Tow of Gilbert: The Cost of Community Services. Herberger Center for Design Excellence, College of Architecture, Arizona State University, Tempe, 1998. 